\title{
PELAKSANAAN SUPERVISI PENDIDIKAN DALAM MENINGGKATKAN PROFESIONALISME GURU
}

\author{
Aula Oktariyani \\ e-mail : aulaoktariyani@gmail.com
}

\begin{abstract}
Abstrak
Kualitas belajar mengajar ini sangat di pengaruhi oleh kualitas kinerja guru. Untuk meningkatkan kemampuan dalam melaksanakan proses pembelajaran, diperlukan perhatian dari penanggung jawab sistem pendidikan secara terus menerus. Supervisi pengajaran merupakan pekerjaan profesional, yang menuntut persyaratan sebagaimana layaknya pekerjaan profesional lainnya. Tugas seorang supervisor adalah untuk membantu, mendorong, dan memberikan keyakinan kepada guru bahwa proses belajar mengajar dapat dan harus diperbaiki. Kegiatan supervisi dilaksanakan melalui berbagai proses pemecahan masalah pengjaran dan bertujuan untuk meningkatkan efektivitas dan efisien proses pembelajaran. Supervisi merupakan bantuan kepada guru dalam perbaikan situasi belajar mengajar. Dengan adanya supervisi pendidikan diharapkan dapat meningkatkan profesionalisme guru.
\end{abstract}

Kata kunci: supervisi pendidikan, meningkatkan profesionalisme guru

\section{PENDAHULUAN}

\section{LATAR BELAKANG}

Kepala Sekolah sebagai penanggung jawab pendidikan memiliki tugas utama untuk melaksanakan kegiatan supervisi akademik di sekolah. Pada umumnya, kegiatan supervisi akademik yang paling mudahdan sering dilakukan oleh Kepala Sekolah adalah supervisi akademik dengan teknik kunjungan kelas, yaitu Kepala Sekolah sebagai supervisor mengadakan kunjungan kelas pada saat guru mengajar di kelas. Selain itu, 
supervisi kunjungan kelas ini dapat dipergunakan untukmensupervisi semua guru yang ada di sekolah, baik untuk guru yang baru diangkat, guru pindahan dari sekolah lain, maupun guru senior yang sudah lama mengajar dan mempunyai banyak pengalaman mengajar. Bagi para guru yang merasa kurang profesional dalam melaksanakan tugasnya, pengawasan dan pembinaan yang dilakukan oleh Kepala Sekolah terhadap kinerja para guru tersebut dirasakan sebagai beban yang berat.

Sesuai amanat Undang-Undang Nomor 20 Tahun 2003 Pasal 39 Ayat 2 tentang Sistem Pendidikan Nasional,didalamnya menyebutkan bahwa "Pendidik merupakan tenaga profesional yang bertugas merencanakan dan melaksanakan proses pembelajaran, menilai hasil pembelajaran, melakukan pembimbingan dan pelatihan, serta melakukan penelitian dan pengabdian kepada masyarakat...”. Tanggung jawab dalam peningkatan profesionalisme guru merupakan kewajiban guru sendiri, namun kepala sekolah tetap memiliki andil dalam pembinaanya, melalui supervisi. Kepala sekolah sebagai supervisor mempunyai tanggung jawab dalam peningkatan kemampuan guru, mengelola kegiatan pembelajaran serta peranan penting terhadap perkembangan dan kemajuan sekolah.

Menurut Purwanto (2012) salah satu fungsi kepala sekolah adalah sebagai supervisor pembelajaran yaitu membimbing guru dalam penyusunan program semester dan program satuan pelajaran. Hal ini sesuai dengan Permendiknas No. 13 tahun 2007 tentang Standar Kepala Sekolah/ Madrasah pada kompetensi supervisi bahwa seorang kepala sekolah merencanakan, melaksanakan dan menindak lanjuti hasil supervisi akademik terhadap guru dalam rangka peningkatan profesionalisme guru. Maka kepala sekolah harus melaksanakan supervisi secara baik sesuai dengan fungsi supervisi, menggunakan pendekatan dan teknik yang tepat.

\section{RUMUSAN MASALAH}

1. Apa pengertian supervisi pendidikan?

2. Apa saja pendekatan supervisi?

3. Apa itu profesionalisme guru? 


\section{TUJUAN}

Tujuan tulisan ini adalah mengungkapkan beberapa pendekatan supervisi yang dapat dilakukan oleh kepala sekolah maupun pengawas dalam rangka meningkatkan profesionalitas guru (Sabandi, 2013)

\section{PEMBAHASAN}

\section{SUPERVISI PENDIDIKAN}

Supervisi pendidikan adalah suatu usaha menstimulir, mengkordinir dan membimbing secara kontinyu pertumbuhan guru-guru di sekolah baik secara individual maupun secara kolektif, agar lebih mengerti dan lebih efektif dalam mewujudkan seluruh fungsi pengajaran dengan demikian mereka dapat menstimulir dan membimbing pertumbuhan setiap murid, sehingga dengan demikian mereka mampu dan lebih cakap berpartisipasi dalamasyarakat demokrasi modern (Bordman Et. Al., 1953:5).

Supervisi pendidikan berkembang seiring dengan perkembangan ilmu pengetahuan, teknologi, serta sosial ekonomi dan budaya masyarakat. Supervisi lebih didominasi oleh supervisor dalam bentuk kolaborasi antara supervisor dan guru. Supervisor dan guru bekerjasama dalam meningkatkan kualitas pembelajaran, dan juga untuk membantuguru agar selalu meningkatkan kompetensinya.(Sabandi, 2013)

\section{PENDEKATAN SUPERVISI}

Menurut (Sabandi, 2013) ada beberapa pendekatan supervisi yang popular, yaitu:

a. Supervisi Klinis

Supervisi llinis dilakukan dalam bentuk proses tatap muka yang memungkinkan supervisor dan guru bersama-sama membahas dan menganalisis masalah pembelajaran yang terjadi di kelas dan menemukan mengatasi masalah tersebut.

b. Supervisi Pengembangan

Dalam pendekatan ini supervisor memperlakukan guru sebagai individu yang berada pada berbagai tahap pertumbuhan dan pengembangan. Pendekatan ini didasarkan pada pemikiran bahwa guru memiliki beragam pengalaman, 
kemampuan, dan tingkat pengembangan karir yang berbeda. Karena itu, supervisor menentukan kebutuhan supervisi guru berdasarkan perbedaan individual, keahlian, dan komitmen. Dengan ini supervisor dapat menggunakan bervariasi pendekatan supervisi untuk guru yang berbeda.

c. Supervisi Diferensial

Menurut Glathorn (1997: 3) dalam (Sabandi, 2013)bahwa supervisi diferensial merupakan pendekatan supervisi yang menyediakan pilihan jenis supervisi dan evaluasi yang sesuai dengan kebutuhan guru. Supervisi diferensial mempertimbangkan perbedaan individual antara guru dan hubungan manusia antara supervisor dan guru.

\section{PROFESIONALISME GURU}

Dalam proses pembelajaran, guru merupakan faktor utama dan yang paling menentukan bagi keberhasilan dunia pendidikan. Guru yang dimaksud adalah guru yang memiliki sikap profesional, sebagaimana yang dikemukakan Usman(2010:15) bahwa guru professional adalah orang yang memiliki kemampuan dan keahlian khusus dalam bidang keguruan sehingga ia mampu melaksanakan tugas dan fungsinya sebagai guru dengan kemampuan maksimal. Selain itu, menurut Fathurrohman dan Suryana (2012: 39) bahwa profesionalisme sebagai penunjang kelancaran guru dalam melaksanakan tugasnya, sangat dipengaruhi oleh dua faktor besar yaitu faktor internal yang meliputi minat dan bakat, dan faktor eksternal yaitu berkaitan dengan lingkungan, sarana prasarana, serta berbagai latihan yang dilakukan guru.

Guru merupakan jabatan atau profesi yang memerlukan keahlian khusus sebagai guru, sehingga untuk menjadi guru diperlukan syarat-syarat khusus, apalagi sebagai guru yang profesional harus menguasai betul tentang pendidikan dan pembelajaran dengan berbagai ilmu pengetahuan lainnya yang perlu dibina dan dikembangkan melalui masa pendidikan tertentu. Tugas guru sebagai seorang profesional meliputi mendidik dan mengajaryang berarti guru mempunyai tugas untuk mengembangkan nilai-nilai hidup, ilmu pengetahuan dan teknologi, serta keterampilan pada peserta didik. Sahertian (2010:2) mengemukakan bahwa ciri-ciri guru yang profesional adalah (1) memiliki kemampuan sebagai ahli mendidik dan mengajar, (2) memiliki rasa tanggung jawab, yaitu komitmen dan kepedulian terhadap tugas, dan (3) memiliki rasa kesejawatan dan 
menghayati tugasnya sebagai karier hidup serta menjunjung tinggi kode etik jabatan. Selain dari pendapat tersebut di atas maka seorang guru yang profesional juga harus dapat menjadi orang tua kedua bagi peserta didik di sekolah, harus mampu menarik simpati peserta didik, dan dapat menjadi motivator bagi peserta didiknya dalam belajar.

\section{KESIMPULAN}

Kesimpulan dari tulisan ini yaitu Supervisi pendidikan adalah suatu usaha menstimulir, mengkordinir dan membimbing secara kontinyu pertumbuhan guru-guru di sekolah baik secara individual maupun secara kolektif, agar lebih mengerti dan lebih efektif dalam mewujudkan seluruh fungsi pengajaran dengan demikian mereka dapat menstimulir dan membimbing pertumbuhan setiap murid, sehingga dengan demikian mereka mampu dan lebih cakap berpartisipasi dalamasyarakat demokrasi modern.

Dalam proses pembelajaran, guru merupakan faktor utama dan yang paling menentukan bagi keberhasilan dunia pendidikan. Guru yang dimaksud adalah guru yang memiliki sikap profesional, bahwa guru professional adalah orang yang memiliki kemampuan dan keahlian khusus dalam bidang keguruan sehingga ia mampu melaksanakan tugas dan fungsinya sebagai guru dengan kemampuan maksimal.

\section{DAFTAR PUSTAKA}

Sahertian, P.A. (2010). Konsep dasar \& Teknik SUPERVISI PENDIDIKAN Dalam Rangka Pengembangan Sumber Daya Manusia. Jakarta : PT Rineka Cipta

Faturrohman dan Suryana (2012). Peningkatan Kualitas Pembelajaran Melalui Supervisi Akademik... 107. http://e-journal.ikippgrimadiun.ac.id/index.php/gulawentah

Boardman, et. al. (1953). Democratic Supervision In Scondary School. Massachusetts:

Houghton Miffin Company

Purwanto, N. 2012. Administrasi dan Supervisi Pendidikan. Bandung: Remaja Rosda Karya.

Sabandi, A. (2013). Supervisi Pendidikan Untuk Pengembangan Profesionalitas Guru Berkelanjutan. Jurnal Ilmiah Ilmu Pendidikan, XIII(2), 1-9. Retrieved from http://ejournal.unp.ac.id/index.php/pedagogi/article/view/4275 
